\title{
The relationship between flower size, inbreeding coefficient and inferred selfing rate in British Euphrasia species
}

\author{
GC French ${ }^{1,2}$, RA Ennos ${ }^{2}$, AJ Silverside ${ }^{3}$ and PM Hollingsworth ${ }^{1}$ \\ ${ }^{1}$ Royal Botanic Garden Edinburgh, 20A Inverleith Row, Edinburgh, EH3 5LR, Scotland, UK; ${ }^{2}$ School of Biological Sciences, University of \\ Edinburgh, Kings Buildings, Edinburgh, EH9 3JR, UK; ${ }^{3 B i o l o g i c a l ~ S c i e n c e s, ~ S c h o o l ~ o f ~ E n g i n e e r i n g ~ a n d ~ S c i e n c e, ~ U n i v e r s i t y ~ o f ~ P a i s l e y, ~}$ \\ Paisley, Renfrewshire, PA1 2BE, UK
}

\begin{abstract}
The genus Euphrasia in Britain comprises a taxonomically complex group of self-compatible, morphologically similar, hemi-parasitic, annual plant species of high conservation importance. The 19 diploid and tetraploid taxa currently recognised show striking variation in flower size. The objective of this paper is to determine whether a relationship exists between flower size and breeding system within Euphrasia. Following a survey of flower size variation among the 19 taxa, seven diploid populations, encompassing a broad range of flower sizes, were selected for detailed study. Four nuclear microsatellite loci were used to estimate the
\end{abstract}

inbreeding coefficient $F_{\text {is }}$ within each population. $F_{\text {is }}$ values varied from to $0.17-0.77$ and showed a significant, negative correlation with flower size. These results are best explained as the consequence of variation in selfing rate among the Euphrasia populations, with selfing rate increasing as flower size decreases. The potential factors influencing breeding system evolution in Euphrasia are discussed, together with the role of autogamy in generating taxonomic complexity and facilitating lineage differentiation within the genus.

Heredity (2005) 94, 44-51. doi:10.1038/sj.hdy.6800553

Published online 18 August 2004

Keywords: microsatellites; conservation genetics; taxonomic complexity; $F_{\text {is }}$; breeding system

\section{Introduction}

Insect-pollinated self-compatible plants show a range of mating systems from complete outcrossing to complete selfing. Even within species, different populations may evolve contrasting rates of outcrossing (Charlesworth and Mayer, 1995; Vogler and Kalisz, 2001). The advantages of outcrossing include the production of variable progeny and avoidance of inbreeding depression. In addition, the higher effective population size of outcrossed populations reduces the rate at which rare alleles are lost by drift, and contributes to the maintenance of genetic variation (Jarne and Charlesworth, 1993). Factors favouring selfing include automatic selection for selfing genes and reproductive assurance in areas where there are constraints on allogamous pollination (Schoen et al, 1996; Holsinger, 2000). Self-pollination may evolve by the reduction of herkogamy (antherstigma separation) or dichogamy (timing of antherstigma maturation) (Dole, 1992; Armbruster et al, 2002), and secondary changes in flower structure may then take place with reduction in resource allocation to the reproductive organs (Barrett et al, 1996). This may involve a reduction in flower size (Stebbins, 1970) or pollen:ovule ratio (Cruden, 1977).

A consequence of the evolution of selfing is the separation of a taxon into reproductively isolated units.

Correspondence: PM Hollingsworth, Royal Botanic Garden Edinburgh, 20 A Inverleith Row, Edinburgh EH3 5LR, Scotland, UK.

E-mail: p.hollingsworth@rbge.org.uk

Received 23 June 2003; accepted 18 June 2004; published online 18 August 2004
Transitions from cross- to self-pollination can hence have profound effects on evolutionary diversification within a plant group. Lack of gene exchange may result in the fixation of distinct multilocus genotypes possessing different combinations of character states. This can lead to difficulties in defining species limits. Selfing lines have been variously treated as full species through to unnamed intraspecific variants (Squirrell et al, 2002; Hollingsworth, 2003). The choice of species concept can in turn have a marked impact on conservation strategies. Excessive splitting of a plant group into a high number of species can elevate their representation within a regional endemic flora and this may raise their conservation status (Hollingsworth, 2003). In contrast, lumping together a series of distinct taxa into a single species complex will reduce the conservation attention given to the group.

The genus Euphrasia (Scrophulariaceae) in Britain is a classic example of a taxonomically complex group (19 currently recognised species, of which at least seven are considered endemic, together with 64 accepted hybrid combinations; Silverside, 1991; Stace, 1997). Both diploid and tetraploid taxa occur (Yeo, 1978), and within each ploidy level, species with markedly different degrees of protogyny and flower size are recognised (Pugsley, 1930). Experimental evidence has shown that these annual plants are self-compatible (Darwin, 1876; Yeo, 1966) but not apomictic (Yeo, 1966). The Euphrasia complex could therefore be thought of as a collection of more or less selfing lines, with varying degrees of reproductive isolation among them. The extent of reproductive isolation within a ploidy level would be a function of the breeding system, with increased autogamy leading to increased isolation. 
At present, we have no quantitative information on the extent of self-pollination in Euphrasia, and there are conflicting views on its prevalence in the genus. On the basis of a paucity of observed pollinator visits (mainly hover-flies (Diptera: Syrphidae) and bumble-bees (Bombus, Hymenoptera: Apidae); Yeo, 1966), Pugsley (1930) and others have concluded that all British Euphrasia taxa are highly selfing, irrespective of their floral biology. An alternative view is that selfing rate varies with flower size (Vitek, 1998). Other authors have invoked outcrossing even within small-flowered Euphrasia to account for the parentage of certain hybrid taxa (Yeo, 1978).

Analysis of progeny arrays in the context of a mixed mating model is a common method for estimating outcrossing rates (Ritland, 1990). This requires genotyping of families from a range of maternal parents. The small seeds, poor germination and low survival of hemiparasitic Euphrasia seedlings on their host plants in a glasshouse situation made such an approach impractical (Yeo, 1961). An indirect method for estimating selfing rates is however available. This relies on the fact that, in a diploid population practising a mixture of selfing and random mating, the equilibrium inbreeding coefficient, $F_{\text {is, }}$ is determined by the rate of self-pollination. By measuring $F_{\text {is }}$ in such a population using selectively neutral, polymorphic, co-dominant markers, inferences about its selfing rate can be made (Brown, 1979).

The primary objective of this paper is therefore to investigate whether the observed variation in flower size among Euphrasia populations is associated with differences in their selfing rates. Given the biological constraints of the system, this question has been tackled by measuring the inbreeding coefficient, $F_{\text {is, }}$ within a set of populations that span the full range of flower sizes. The relationship between $F_{\text {is }}$ (used here as surrogate for selfing rate) and flower size has then been determined.

The second objective of the research stems from a need to understand how taxonomic complexity is generated in the Euphrasia group. Specifically, we wish to determine whether the rates of selfing inferred from estimation of $F_{\text {is }}$ are sufficient to create significant reproductive barriers between taxa. Understanding the biological basis of taxonomic complexity is a priority for conservation of Euphrasia taxa that constitute almost $25 \%$ of the vascular plant species listed on the UK Biodiversity Action Plan 'Short List' (HMG, 1995).

\section{Materials and methods}

\section{Flower size measurements}

A comprehensive field survey of flower size variation was undertaken for the 19 recognised taxa of British Euphrasia. A total of 755 plants were sampled from 45 populations throughout the UK (Table 1). In the field single flowers were removed from the first flowering node of each individual and immediately placed on wet tissue, in a petri dish, to prevent drying out. At the same time, the total number of open flowers and total number of branches were recorded from each plant sampled.

Within $24 \mathrm{~h}$ of collection, the corollas were dissected into their upper and lower lobes. These were measured immediately or fixed onto card with a transparent tape to allow measurements to be taken later. Using this fixation method, no discernable shrinkage of corolla lobes was observed. For each corolla, the depth and inner and outer width of the central lower lip were measured under a dissecting microscope, together with the length of the upper lip (Figure 1). By assuming that the lower lip approximated a trapezium in shape, it was possible to calculate its area, a character thought to be most indicative of the attractiveness of the flower to pollinators (Karlsson, 1982).

\section{Genetic analyses}

From the floral survey, seven populations were selected to represent the maximal variation in average corolla size among diploid taxa (Figure 1, Table 1). Tetraploid taxa were not analysed due to difficulties involved in the scoring of their genotypes, and subsequent estimation of $F_{\text {is }}$ values. The diploid populations selected included three populations of Euphrasia officinalis subsp rostkoviana (D3; D4; D5), two populations of E. vigursii (D15; D16), one population of E. officinalis subsp anglica (D1) and one population of $E$. rivularis (D10). The population of E. officinalis subsp anglica consisted of two subpopulations separated by approximately $50 \mathrm{~m}$; these were analysed separately (D1A, D1B).

From each of the seven populations chosen, fresh plant tissue was collected from 15-30 individuals for DNA analysis. Samples consisting of a minimum of three leaves per plant were placed in a $1.5 \mathrm{ml}$ eppendorf tube and frozen in the field with a Taylor Wharton cryopreserver $\left(-197^{\circ} \mathrm{C}\right)$, before long-term storage at $-80^{\circ} \mathrm{C}$.

DNA extraction was performed directly in the eppendorf tubes, using the hexadecyltrimethylammonium bromide (CTAB) method, as described by Saghai-Maroof et al (1984), with the modifications of Doyle and Doyle (1987). 2-Mercaptoethanol (0.2\%) and insoluble polyvinylpolypyrrolidine (PVPP; $0.1 \%$ ) were added to the $2 \times$ CTAB buffer (1.4 M NaCl, $100 \mathrm{mM}$ Tris- $\mathrm{HCl}, \mathrm{pH} 8.0$, $20 \mathrm{mM}$ EDTA, 2\% CTAB). Two chloroform/isoamyl alcohol extractions were performed, and after precipitation with freezer-cold isopropanol overnight, the resultant DNA pellet was resuspended in $50 \mu \mathrm{l}$ of Tris-EDTA, $\mathrm{pH} 8$ (TE). This DNA was then stored at $-20^{\circ} \mathrm{C}$.

Microsatellite markers were chosen for this study because they have high allelic diversity resulting from their high mutation rate (Jarne and Lagoda, 1996). They therefore displayed the allelic variation required for the estimation of $F_{\text {is }}$ even in highly inbreeding species where gene diversities are typically lower than in outcrossing species (Hamrick and Godt, 1996).

Four microsatellite loci (Ene1, Ene2, Ene3, Ene4) were amplified using primers and PCR conditions as described by French et al (2003). The PCR products were run on an ABI 377 DNA sequencer, followed by gel image analysis and allele size scoring using ABI Genescan $^{\circledR}$ software (version 3.1.2) (Applied Biosystems).

\section{Data analysis}

The microsatellite data were formatted for analysis using Microsatellite Toolkit (Park, 2001). For each population, the mean number of alleles per locus $(A)$, the proportion of polymorphic loci $(P)$, the mean observed heterozygosity $\left(H_{\mathrm{O}}\right)$ and the mean expected heterozygosity $\left(H_{\mathrm{E}}\right)$ at Hardy-Weinberg equilibrium were calculated using GDA: version 1.0 (Lewis and Zaykin, 2001). Wright's 
Table 1 Location and average corolla measurements of 45 populations of British Euphrasia taxa

\begin{tabular}{|c|c|c|c|c|c|c|c|}
\hline Pop. & Taxon & Region & Population & Grid reference & No. & $\begin{array}{l}\text { Average area } \pm S D \text { of } \\
\quad \text { lower lip }\left(\mathrm{mm}^{2}\right)\end{array}$ & $\begin{array}{c}\text { Average length } \pm S D \text { of } \\
\text { upper lip }(\mathrm{mm})\end{array}$ \\
\hline \multicolumn{8}{|c|}{ Diploid } \\
\hline D1 & E. officinalis subsp anglica & South-west England & Kit Hill & SX/374.715 & 29 & $5.00 \pm 1.17$ & $6.71 \pm 0.70$ \\
\hline D3 & E. officinalis subsp rostkoviana & Wales & Gower & SS/539.928 & 26 & $10.66 \pm 1.61$ & $9.53 \pm 0.56$ \\
\hline D4 & E. officinalis subsp rostkoviana & Wales & Caeae Llety-cyli & $\mathrm{SN} / 603.535$ & 26 & $7.87 \pm 1.13$ & $8.28 \pm 0.54$ \\
\hline D5 & E. officinalis subsp rostkoviana & Wales & Devil's Bridge & $\mathrm{SN} / 751.735$ & 25 & $7.89 \pm 1.59$ & $8.35 \pm 0.71$ \\
\hline D7 & E. rivularis & Wales & Snowdon & $\mathrm{SH} / 605.558$ & 22 & $5.06 \pm 1.05$ & $6.13 \pm 0.55$ \\
\hline D8 & E. rivularis & Wales & Cwm Glas & $\mathrm{SH} / 616.565$ & 19 & $5.69 \pm 1.18$ & $6.89 \pm 0.68$ \\
\hline D9 & E. rivularis & North-west England & Stickle Tarn & NY / 290.083 & 12 & $7.29 \pm 1.17$ & $6.94 \pm 0.38$ \\
\hline D10 & E. rivularis & North-west England & Honiston Pass & NY / 226.134 & 26 & $3.95 \pm 0.85$ & $5.85 \pm 0.49$ \\
\hline D12 & E. vigursii & South-west England & Carvannel Downs & SW/641.446 & 27 & $4.65 \pm 0.79$ & $5.96 \pm 0.36$ \\
\hline D13 & E. vigursii & South-west England & Porthtowan & SW/688.477 & 30 & $5.15 \pm 1.15$ & $6.26 \pm 0.65$ \\
\hline D15 & E. vigursii & South-west England & Tregrethona Downs & SW/959.628 & 24 & $6.64 \pm 1.19$ & $7.10 \pm 0.70$ \\
\hline D16 & E. vigursii & South-west England & Treslea Downs & $\mathrm{SX} / 134.683$ & 27 & $6.03 \pm 1.63$ & $6.30 \pm 0.61$ \\
\hline \multicolumn{8}{|c|}{ Tetraploid } \\
\hline $\mathrm{T} 3$ & E. arctica subsp borealis & North-west England & Rosthwaite & NY / 255.159 & 28 & $6.37 \pm 0.87$ & $6.96 \pm 0.42$ \\
\hline T5 & E. arctica subsp borealis & Mid Scotland & Tulloch Moor & $\mathrm{NH} / 960.161$ & 15 & $9.05 \pm 2.02$ & $7.90+0.65$ \\
\hline T7 & E. arctica subsp borealis & North-west Scotland & Siabost & $\mathrm{NB} / 271.473$ & 19 & $11.27 \pm 3.33$ & $8.24 \pm 0.77$ \\
\hline T9 & E. arctica subsp borealis & North Scotland & Durness & NC/405.669 & 11 & $10.63 \pm 2.71$ & $7.96 \pm 1.16$ \\
\hline T10 & E. arctica subsp borealis & North Scotland & Reay & NC/958.653 & 20 & $13.07 \pm 2.26$ & $8.98 \pm 0.72$ \\
\hline T11 & E. cambrica & Wales & Snowdon & $\mathrm{SH} / 605.558$ & 8 & $0.87 \pm 0.30$ & $3.64 \pm 0.24$ \\
\hline T13 & E. campbelliae & North-west Scotland & Mealasta & NA/994.235 & 6 & $3.80 \pm 0.83$ & $6.59 \pm 0.38$ \\
\hline T16 & E. confusa & South-west England & Kit Hill & SX/374.715 & 13 & $3.03 \pm 0.92$ & $5.85 \pm 0.59$ \\
\hline T17 & E. confusa & North Scotland & Inchnadamp & NC/267.213 & 5 & $3.21+0.32$ & $5.82+0.52$ \\
\hline T18 & 'E. fharaidensis' & North Scotland & Inchnadamp & $\mathrm{NC} / 272.210$ & 12 & $2.51 \pm 0.44$ & $4.97 \pm 0.21$ \\
\hline T19 & 'E. fharaidensis' & North Scotland & Rhiconich & $\mathrm{NC} / 253.523$ & 11 & $2.25 \pm 0.37$ & $5.10 \pm 0.43$ \\
\hline $\mathrm{T} 23$ & E. foulaensis & North-west Scotland & Mealasta & NA/993.240 & 6 & $2.08+0.51$ & $5.11+0.22$ \\
\hline $\mathrm{T} 24$ & E. foulaensis & North-west Scotland & Mangurstadh & NB/005.315 & 10 & $2.33 \pm 0.54$ & $5.05 \pm 0.28$ \\
\hline T29 & E. frigida & Mid Scotland & Creag an Lochain & NN/592.411 & 15 & $3.15 \pm 0.61$ & $6.46 \pm 0.90$ \\
\hline T36 & E. heslop-harrisonii & North-west Scotland & Seilebost & NG/083.668 & 13 & $2.65 \pm 0.98$ & $5.62 \pm 0.65$ \\
\hline T37 & E. marshallii & North Scotland & Betty Hill & $\mathrm{NC} / 705.628$ & 20 & $3.91 \pm 0.31$ & $6.09 \pm 0.40$ \\
\hline T38 & E. marshallii & North Scotland & Melness & $\mathrm{NC} / 577.653$ & 12 & $6.69 \pm 1.27$ & $6.46 \pm 0.39$ \\
\hline T40 & E. micrantha & South-west England & Wheal Busy & $\mathrm{SW} / 742.423$ & 20 & $2.46+0.58$ & $5.67+0.37$ \\
\hline T41 & E. micrantha & South-west England & Chapel Porth & SW/697.494 & 9 & $1.44 \pm 0.39$ & $4.40 \pm 0.68$ \\
\hline T42 & E. micrantha & Mid Scotland & Tulloch Moor & $\mathrm{NH} / 962.167$ & 17 & $3.25 \pm 0.58$ & $5.75 \pm 0.56$ \\
\hline $\mathrm{T} 43$ & E. nemorosa & Wales & Cae Biaen Dyffryn & SN/606.447 & 14 & $2.34 \pm 0.52$ & $6.23 \pm 0.65$ \\
\hline T46 & E. nemorosa & North-west Scotland & Dail Beag & $\mathrm{NB} / 227.458$ & 20 & $5.70+1.08$ & $6.83+0.39$ \\
\hline $\mathrm{T} 48$ & E. nemorosa & North Scotland & Fharaid Head & $\mathrm{NC} / 392.687$ & 19 & $7.30 \pm 1.46$ & $7.27 \pm 0.79$ \\
\hline T49 & E. nemorosa & North Scotland & Dunnett Bay & $\mathrm{ND} / 223.700$ & 20 & $10.76 \pm 2.54$ & $7.73 \pm 0.73$ \\
\hline T50 & E. ostenfeldii & Wales & Snowdon & $\mathrm{SH} / 602.556$ & 10 & $2.18+0.36$ & $5.72+0.51$ \\
\hline T52 & E. ostenfeldii & North Scotland & Inchnadamp & $\mathrm{NC} / 272.210$ & 14 & $1.54 \pm 0.22$ & $4.83 \pm 0.27$ \\
\hline T54 & E. pseudokerneri & East England & Therfield Heath & TL/330.395 & 20 & $10.25 \pm 1.87$ & $9.43 \pm 0.78$ \\
\hline T55 & E. pseudokerneri & East England & Fleam Dyke & TL/545.545 & 20 & $11.39+2.12$ & $9.28+1.09$ \\
\hline T56 & E. pseudokerneri & East England & Devil's Ditch & TL/617.616 & 20 & $11.93 \pm 1.77$ & $9.17 \pm 0.89$ \\
\hline T57 & E. scottica & North-west England & Honiston Pass & NY / 230.136 & 5 & $1.74 \pm 0.50$ & $4.75 \pm 0.43$ \\
\hline T62 & E. scottica & North-west Scotland & Carlabhagh & $\mathrm{NB} / 190.413$ & 14 & $2.62 \pm 0.29$ & $4.98 \pm 0.32$ \\
\hline T65 & E. tetraquetra & South-west England & Wicca Pool & SW / 465.403 & 9 & $2.08+0.36$ & $5.19+0.39$ \\
\hline T67 & E. tetraquetra & Wales & Mewslade & SS/419.873 & 7 & $3.43 \pm 1.16$ & $5.81 \pm 0.42$ \\
\hline
\end{tabular}

'Euphrasia fharaidensis' is an informal taxon name given to a recognisable entity from the NW of Scotland that has yet to be formerly described. For all other taxa, nomenclature follows Yeo (1978) and Silverside (1991). 


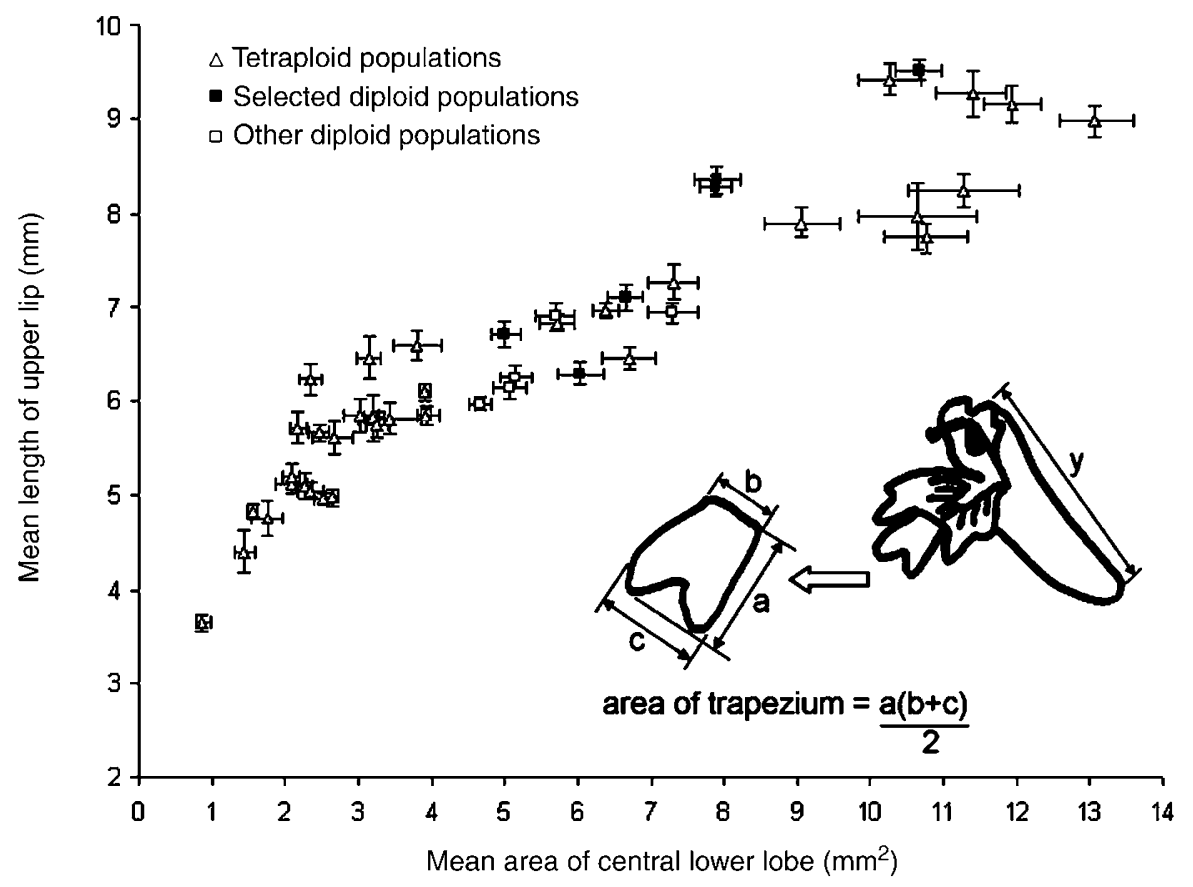

Figure 1 Average corolla size from the 45 Euphrasia populations listed in Table 1. Diploid populations used for the genetic analysis are represented by filled squares. Floral measurements indicated in figure, $y=$ length of upper lip.

fixation index, $F_{\text {is }}$ (Wright, 1965), was computed for each locus and averaged across all loci, for each population using FSTAT version 2.9.3.2 (Goudet, 2001). Standard errors and significance values were estimated based on randomisation tests. For each population, the mean and standard error were calculated for the area of the lower lip, number of open flowers per plant and number of branches. Correlations between the inbreeding coefficient of populations and population mean values for all morphological characters were calculated using the statistical package, MINITAB.

\section{Results}

\section{Morphological variation}

Across all taxa, the area of the lower lip ranged from 13.07 to $0.87 \mathrm{~mm}^{2}$ (Table 1, Figure 1). The largest flowers were found in the widespread tetraploid species $E$. arctica subsp borealis and the smallest flowers in the endemic tetraploid E. cambrica. Within the seven diploid taxa selected for genetic analysis, the area of the lower lip ranged from 10.66 to $3.95 \mathrm{~mm}^{2}$. E. officinalis subsp rostkoviana had the largest flowers, E. officinalis subsp anglica and E. rivularis the smallest and E. vigursii was intermediate (Table 1, Figure 1). In populations of these diploid taxa, the correlation between mean flower size and either mean total number of flowers per plant or mean number of branches was not significant $(r=0.399$, $P=0.328 ; r=0.280, P=0.502$, respectively). There was also no significant correlation between the mean number of branches and mean total number of flowers in a population $(r=0.568, P=0.142)$.

\section{Microsatellite variation}

In the total data set all loci were polymorphic, with 38 alleles detected (12 from Ene1, 17 from Ene2, six from Ene3 and three from Ene4). Within taxa, the proportion of loci that were polymorphic was $100 \%$ in E. officinalis subsp rostkoviana, E. vigursii and E. rivularis, but only three of the four loci were polymorphic in the population of E. officinalis subsp anglica. At the population level, the greatest allelic and gene diversity was found in population D5 of E. officinalis subsp rostkoviana ( $A=5.5$; $H_{\mathrm{E}}=0.606 ; H_{\mathrm{O}}=0.459 ;$ Table 2). The lowest diversity was found in population D15 of E. vigursii, which was fixed for a single allele at each locus $\left(A=1.0 ; H_{\mathrm{E}}=0.0\right.$; $\left.H_{\mathrm{O}}=0.0\right)$, and also in one subpopulation of $E$. officinalis subsp anglica which was also invariant (Table 2). The lack of genetic variation in these populations precluded the calculation of their inbreeding coefficients.

In the remaining populations showing allelic variation, 21 of the 23 single-locus estimates of $F_{\text {is }}$ were positive, showing a strong deficit of heterozygotes compared with Hardy-Weinberg expectations. Multilocus $F_{\text {is }}$ values were all positive and ranged from $F_{\text {is }}=0.166$ in population D4 to $F_{\text {is }}=0.770$ in population D10 (Table 2). All but one population (D4) showed a significant deviation from panmixia $(P<0.05$, Table 2$)$.

\section{Inbreeding coefficient and flower morphology}

There was a significant negative correlation between flower size and $F_{\text {is }}(r=-0.893, P=0.016)$ (Figure 2) and this explained $80 \%$ of the variation. The populations with the smallest flowers (area of lower lip $<5 \mathrm{~mm}^{2}$ ) had the highest inbreeding coefficients $\left(F_{\text {is }}>0.74\right)$, whereas larger flowered populations (area of lower lip $>7.5 \mathrm{~mm}^{2}$ ) had smaller inbreeding coefficients $\left(F_{\text {is }}<0.25\right)$. 


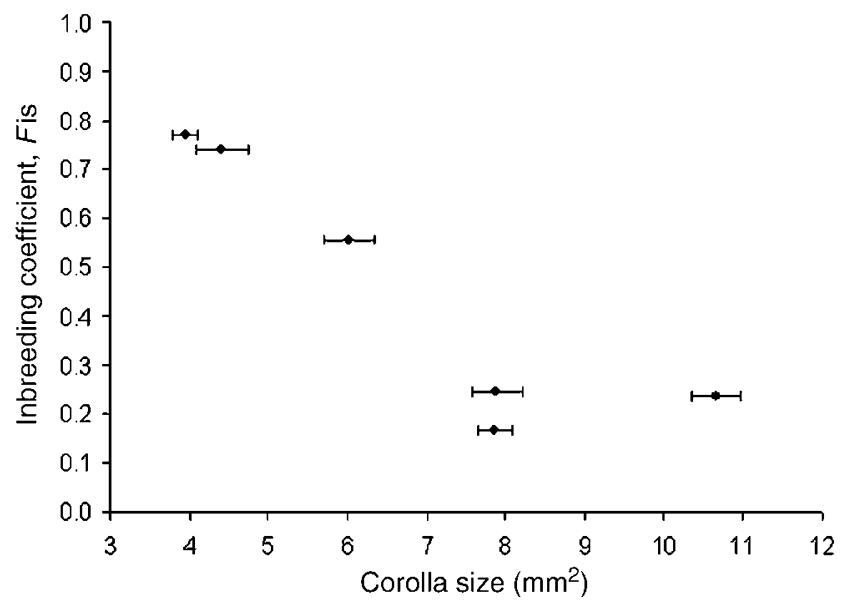

Figure 2 Relationship between corolla size (the area of the central lower lobe) and inbreeding coefficient, $F_{\text {is, }}$ for each of the six Euphrasia populations.

No significant correlations were found between $F_{\text {is }}$ and either the mean number of flowers or mean number of branches per plant $(r=-0.701, P=0.121 ; r=-0.583$, $P=0.224$, respectively). There was also no significant correlation between flower size and levels of allelic diversity $(r=0.324, P=0.433)$, gene diversity $(r=0.260$, $P=0.533)$ or percentage of loci that were polymorphic $(r=0.234, P=0.577)$.

\section{Discussion}

Interpretation of $F_{\text {is }}$

This study has revealed positive values of $F_{\text {is }}$ in all populations of Euphrasia sampled. For five of the six populations $F_{\text {is }}$ values are significantly greater than zero. In addition, a strong and statistically significant negative correlation has been demonstrated between the inbreeding coefficient $F_{\text {is }}$ and the mean population flower size.

Positive estimates of $F_{\text {is }}$ usually indicate an inbreeding mating system. However, positive $F_{\text {is }}$ values may also be recorded in outcrossing populations under certain circumstances. The first is where high frequencies of null alleles occur at the marker loci used to estimate $F_{\text {is }}$ and the second is where there is strong population substructure.

Two observations suggest that null alleles do not account for the positive $F_{\text {is }}$ values reported here. The first is that within populations $F_{\text {is }}$ estimates are relatively consistent over loci, and do not appear to be caused by abnormal behaviour of particular loci (Table 2). The second is that nonamplifying individuals (homozygous nulls) were not detected at any of the microsatellite loci in either the populations scored here or in the samples used initially to screen the markers.

Evidence to demonstrate that population substructure may generate positive $F_{\text {is }}$ estimates comes from reanalysis of data from the E. officinalis subsp anglica population (Table 2). This comprises two subpopulations, D1A and D1B, separated by approximately $50 \mathrm{~m}$. Subpopulation D1B is polymorphic at three microsatellite loci and is genetically differentiated from population 
D1A, which is fixed at all microsatellite loci. When data from the genetically differentiated populations are combined, the estimate of $F_{\text {is }}$ increased from 0.741 (subpopulation D1B only) to 0.875 (combined subpopulations). Thus, population subdivision could potentially account for a fraction of the observed inbreeding values recorded. However, it should be noted that strong population subdivision is not a feature of outcrossing species (Ennos, 2001) and it is unlikely that simple population substructure within predominantly outcrossing taxa could account for either the levels or patterns of variability of $F_{\text {is }}$ reported in this study. Thus, the most likely explanation for the results is that the variation in estimated $F_{\text {is }}$ in Euphrasia reflects differences in rates of selfing among populations. High selfing rates are associated with small flower size.

Where populations are at inbreeding equilibrium, the value of $F_{\text {is }}$ can be used to calculate an estimate of the rate of selfing $s$ using the relationship $s=\left(2 F_{\text {is }}\right) /\left(1+F_{\text {is }}\right)$ (Allard et al, 1969). If inbreeding equilibrium were assumed in our populations, then the smallest inferred selfing rates would be $s=0.4$, found in E. officinalis subsp rostkoviana, whose populations have large showy flowers. In contrast, the maximum inferred rate of selfing would be $s=0.85$, found in the small-flowered taxa, $E$. officinalis subsp anglica and E. rivularis. This extremely high selfing rate is in keeping with other features of these taxa that include poorly developed nectaries, and a minimal degree of herkogamy and dichogamy (Schulz, as reported by Knuth, 1909).

While the correlation between flower size and inbreeding coefficient suggests that within flower pollination is the most likely route for self-pollination, geitonogamous pollination could also occur in Euphrasia. If this were the case, a positive relationship would be expected between $F_{\text {is }}$ estimates and flower number and branch number per plant. However, no significant correlations were detected. This suggests that geitonogamy is unlikely to be important in determining inbreeding coefficients within Euphrasia populations.

\section{Potential factors influencing the breeding system in British Euphrasia}

This study indicates that substantial self-pollination is likely to be occurring within Euphrasia, but has not examined the ecological and genetic factors driving the evolution of autogamy. Selection for high levels of selfpollination is likely under conditions of poor pollinator availability, and such a breeding behaviour has been proposed for the small-flowered E. willkommii, which occurs in dense populations, on high mountains, in Spain. There, despite insect visitation as low as 3\%, a 2year study found that approximately $80 \%$ of the ovules were pollinated (Gómez, 2002).

In addition to the observed poor pollinator service (Yeo, 1966), it is possible that the genetic load is below the level at which selfing genes are at a selective advantage (Jarne and Charlesworth, 1993). We may speculate that high biparental inbreeding from recurrent fluctuations in population size and limited gene flow in these annual plants (Molau, 1993) may be important in the purging of deleterious alleles and so reducing the genetic load. Once genetic load is low, selfing may easily evolve.

\section{Stability of intermediate selfing rates}

It is not clear whether populations with intermediate flower sizes represent (a) transient flower sizes from which an increase or a decrease in size will eventually be selected, or (b) an equilibrium situation in which facultative autogamy is promoted due to pollinator unpredictability, resulting in selection for the capacity to either self or outcross (Vogler and Kalisz, 2001). In large-flowered taxa such as E. officinalis subsp rostkoviana, some selfing occurs (Figure 2, Table 2). The potential reasons for this include geitonogamy, facilitated selfing and delayed selfing. Indeed, marked corolla tube elongation occurs following anther dehiscence, which reduces initial anther-stigma separation (Pugsley, 1930). This elongation may represent such a delayed selfing mechanism and serve as a useful adaptive mechanism of reproductive assurance for these annual plants.

\section{Reproductive isolation and the potential for taxonomic diversification}

The correlation between flower size and inbreeding coefficient is informative with regard to diversification mechanisms in the genus. High levels of self-pollination are one potential mechanism behind taxon diversification and differentiation. As homozygosity increases by $50 \%$ for each generation of complete selfing, a large genetic distance can quickly develop between selfing lines and outcrossing progenitor taxa, and selfing taxa can acquire novel multilocus character combinations (Baker, 1959; Squirrell et al, 2002). Thus, as with other plants (Jain, 1976), isolation caused by breeding system transitions may contribute towards the high diversity of often sympatric Euphrasia species in Britain. If one extrapolates from the inferred selfing rates measured in this study to all British Euphrasia species, the predominance of self-pollination is evident (Figure 3 ). Out of the 19 taxa, 11 have flower sizes that fall within a zone of inferred selfing of $>80 \%$. A further four taxa have mean flower sizes which are of a similar or smaller size than the population of E. vigursii (mean area of central lower lip $6.03 \mathrm{~mm}^{2}$ ) that had a mean inferred selfing rate of $s=0.711\left(F_{\text {is }}=0.551\right)$. Thus, the recurrent evolution of autogamous lineages provides one explanation for the

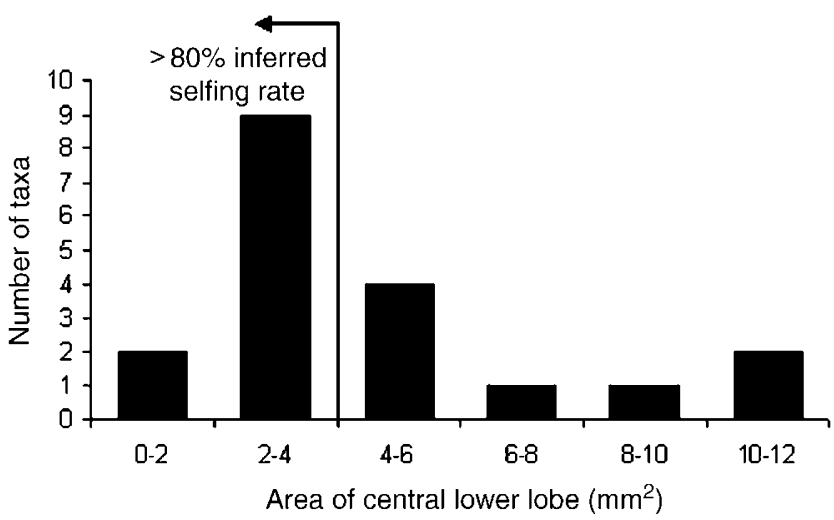

Figure 3 The number of British Euphrasia species in relation to their mean flower sizes, based on the data in Table 1 . The area to the left of the line is the area in which inferred selfing rates exceed $80 \%$ (eg an $F_{\text {is }}$ estimate $>0.66$ ), based on extrapolation from the genetic analysis of the populations examined in the current study. 
presence of high levels of Euphrasia diversity in recently glaciated landscape such as the British Isles. A similar process has been described within British Epipactis. Using isozyme and chloroplast RFLP analyses, Squirrell et al (2002) showed that lineage diversification within the Epipactis leptochila complex has probably been the result of the recurrent origin of selfing lines from the outcrossing progenitor, Epipactis helleborine.

Confirmation that Euphrasia has a mixed mating system with differing rates of inbreeding associated with variation in floral morphology is an important first step in the understanding of the processes driving the morphological diversification within this taxonomically complex plant group. Further examination of the ecological conditions promoting recurrent allogamousautogamous shifts in Euphrasia may help towards a greater understanding of processes involved in evolutionary diversification of Euphrasia and other taxonomically complex plant groups. This will help in establishing and setting conservation priorities, and offers the potential to design conservation programmes in which the evolutionary process, and not just its products, is an integral conservation goal (Hollingsworth, 2003).

\section{Acknowledgements}

This work was funded primarily by an NERC CASE studentship to Graham French, with support from Scottish Natural Heritage, English Nature and the Countryside Commission for Wales. We are grateful to Jane Squirrell, Michelle Hollingsworth, Christina Oliver and Alex Ponge for their help in the laboratory and field. The Royal Botanic Garden Edinburgh is funded by the Scottish Executive Environment and Rural Affairs Department.

\section{References}

Allard RW, Jain SK, Workman PL (1969). Genetics of inbreeding populations. Adv Genet 14: 55-131.

Armbruster SW, Mulder CPH, Baldwin BG, Kalisz S, Wessa B, Nute H (2002). Comparative analysis of late floral development and mating-system evolution in Tribe Collinsieae (Scrophulariaceae). Am J Bot 89: 37-49.

Baker HG (1959). Reproductive methods as a factor in speciation in flowering plants. Cold Spring Harb Symp Quant Biol 24: 177-191.

Barrett SCH, Harder LD, Worley AC (1996). The comparative biology of pollination and mating in flowering plants. Philos Trans R Soc Lond B Biol Sci 351: 1271-1280.

Brown ADH (1979). Enzyme polymorphism in plant populations. Theor Appl Genet 15: 1-42.

Charlesworth D, Mayer S (1995). Genetic variability of plant characters in the partial inbreeder Collinsia heterophylla (Scrophulariaceae). Am J Bot 82: 112-120.

Cruden RW (1977). Pollen-ovule ratios. A conservative indicator of breeding systems in flowering plants. Evol Int J Org Evolution 31: 32-46.

Darwin C (1876). The Effects of Cross and Self Fertilisation in the Vegetable Kingdom, Murray: London, UK.

Dole JA (1992). Reproductive assurance methods in three taxa of the Mimulus guttatus complex (Scrophulariaceae). Am J Bot 79: 650-659.

Doyle JJ, Doyle JL (1987). A rapid DNA isolation procedure for small quantities of fresh leaf material. Phytochem Bull 19: $11-15$.
Ennos RA (2001). Inferences about spatial processes in plant populations from the analysis of molecular markers. In: Silvertown J, Antonovics J (eds) Integrating Ecology and Evolution in a Spatial Context, Blackwell Science: Oxford. pp 45-71.

French GC, Hollingsworth PM, Ennos RA (2003). Isolation of polymorphic microsatellite for British Euphrasia L. Mol Ecol Notes 3: 626-628.

Gómez JM (2002). Self-pollination in Euphrasia willkommii Freyn (Scrophulariaceae), an endemic species from the alpine of the Sierra Nevada (Spain). Plant Syst Evol 232: 63-71.

Goudet J (2001). FSTAT, a program to estimate and test gene diversities and fixation indices (version 2.9.3.1). Available from http://www.unil.ch/izea/softwares/fstat.html.

Hamrick JL, Godt MJW (1996). Effects of life history traits on genetic diversity in plant species. Philos Trans $R$ Soc Lond $B$ Biol Sci 351: 1291-1298.

HMG (Her Majesties Government (1995). Biodiversity: The UK Steering Group Report, HMSO: London, UK.

Hollingsworth PM (2003). Taxonomic complexity, population genetics and plant conservation in Scotland. Bot J Scotl 55: 55-63.

Holsinger KE (2000). Reproductive systems and evolution in vascular plants. Proc Natl Acad Sci USA 97: 7037-7042.

Jain SK (1976). The evolution of inbreeding in plants. Annu Rev Ecol Syst 7: 469-495.

Jarne P, Charlesworth D (1993). The evolution of the selfing rate in functionally hermaphrodite plants and animals. Annu Rev Ecol Syst 24: 441-466.

Jarne P, Lagoda PJL (1996). Microsatellites, from molecules to populations and back. Trends Ecol Evol 11: 424-429.

Karlsson T (1982). Euphrasia rostkoviana i Sverige. Vaxtekologiska Studier 15: 1-116.

Knuth P (1909). Handbook of Flower Pollination 3 (translated by JR Ainsworth Davis). Clarendon Press: Oxford, UK.

Lewis PO, Zaykin D (2001). Genetic data analysis: computer program for the analysis of allelic data. Version 1.0 (d16c) Available from http://lewis.eeb.uconn.edu/lewishome/ software.html.

Molau U (1993). Phenology and reproductive ecology in six subalpine species of Rhinanthoideae (Scrophulariaceae). Opera Bot 121: 7-17.

Park SDE (2001). Microsatellite toolkit Available from http:// acer.gen.tcd.ie/ sdepark/ms-toolkit/.

Pugsley HW (1930). A revision of the British Euphrasiae. J Linn Soc Lond Bot 48: 467-544.

Ritland K (1990). A series of FORTRAN computer programs for estimating plant mating systems. I Hered 81: 235-237.

Saghai-Maroof MA, Soliman KM, Jorgensen RA, Allard RW (1984). Ribosomal DNA spacer length polymorphism in barley: Mendelian inheritance, chromosomal location and population dynamics. Proc Natl Acad Sci USA 81: 8014-8019.

Schoen DJ, Morgan MT, Batallion T (1996). How does selfpollination evolve? Inferences from floral ecology and molecular genetic variation. Philos Trans $R$ Soc Lond B Biol Sci 351: 1281-1290.

Silverside AJ (1991). The identity of Euphrasia officinalis L and its nomenclature implications. Watsonia 18: 343-350.

Squirrell J, Hollingsworth PM, Bateman RM, Tebbit MC, Hollingsworth ML (2002). Taxonomic complexity and breeding system transitions: conservation genetics of the Epipactis leptochila complex. Mol Ecol 11: 1957-1964.

Stace CA (1997). New Flora of the British Isles, 2nd edn. Cambridge University Press: Cambridge, UK.

Stebbins GL (1970). Adaptive radiation of reproductive characteristics in Angiosperms I: pollination mechanisms. Annu Rev Ecol Syst 1: 307-326.

Vitek E (1998). Are the taxonomic concepts of agamospermous genera useful for autogamous groups - a critical discussion using the example of Euphrasia (Scrophulariaceae). Folia Geobot 33: 349-352. 
Vogler DM, Kalisz S (2001). Sex among the flowers: the distribution of plant mating systems. Evol Int J Org Evol 55: 202-204.

Wright S (1965). The interpretation of population structure by $F$-statistics with special regards to systems of mating. Evol Int J Org Evol 38: 1358-1370.
Yeo PF (1961). Germination, seedlings and the formation of haustoria in Euphrasia. Watsonia 5: 11-22.

Yeo PF (1966). The breeding relationships of some European Euphrasiae. Watsonia 6: 216-245.

Yeo PF (1978). A taxonomic revision of Euphrasia in Europe. Bot J Linn Soc 77: 223-334. 